Jurnal Ilmu Dan Teknologi Kesehatan

Vol 8, No 2, March 2021,

ISSN: 2338-9095 (Print)

ISSN: 2338-9109 (online)

\title{
Prevalence of Escherichia Coli, Salmonella Sp, Staphylococcus Aureus Bacteria in Chicken Meat of Traditional Market Surabaya City
}

\author{
Ulfa Dwi Karisma, Nurul Wiqoyah, Suhintam Pusarawati \\ Airlangga University, Indonesia \\ Email: ulfadwikarisma729@gmail.com
}

\section{Article history}

Posted, Jan 7th, 2021

Reviewed, Jan 19th, 2021

Received, March, 15th, 2021

\begin{abstract}
Foodborne disease is a disease caused by contaminated food. Chicken meat is very susceptible to contamination by bacteria. Escherichia coli, Salmonella sp, and Staphylococcus aureus are types of bacteria found in chicken meat. The purpose of this study was to see how many Escherichia coli, Salmonella sp, and Staphylococcus aureus colonies in raw chicken meat in traditional markets in Surabaya City. The research sample used was 30 samples of chicken meat taken in 5 traditional markets in Surabaya. Six chicken meat sellers were taken with 1 sample and put in the sterile tube from each market. The test was carried out using the Total Plate Count (TPC) method. The TPC test results showed that all samples were contaminated with E. coli, with the most colony being $2.2 X_{10^{-7}} \mathrm{CFU} / \mathrm{g}$ while the minor colony was $5 \times 10^{-4} \mathrm{CFU} / \mathrm{g}$. There are two samples contaminated with Salmonella sp, in the G market and the $W$ market, with code D6 $4.7 \times 10^{-6} \mathrm{CFU} / \mathrm{g}$ and code E5 $1 \times 10^{-6} \mathrm{CFU} / \mathrm{g}$. Meanwhile, S. aureus was only found in the W market with sample codes E1 \& E6, and each sample had a colony of $2.7 \times 10^{-7} \mathrm{CFU} / \mathrm{g}$ and $2 \times 10^{-5} \mathrm{CFU} / \mathrm{g}$.
\end{abstract}

Keywords: chicken meat; Escherichia coli; Salmonella sp; Staphylococcus aureus.

\begin{abstract}
ABSTRAK
Foodborne disease adalah penyakit yang disebabkan oleh makanan yang terkontaminasi. Daging ayam sangat rentan tercemar oleh bakteri. Escherichia coli, Salmonella sp dan Staphylococcus aureus merupakan jenis spesies bakteri yang dapat ditemukan pada daging ayam. Penelitian ini bertujuan untuk mengetahui jumlah koloni Escherichia coli, Salmonella $s p$ dan Staphylococcus aureus pada daging ayam mentah di pasar tradisional Kota Surabaya. Sampel penelitian yang digunakan adalah 30 sampel daging ayam yang diambil di 5 pasar tradisional di Surabaya. Tiap pasar diambil 6 penjual daging ayam dengan masing-masing 1 sampel dan dimasukkan ke dalam pot steril. Pengujian dilakukan dengan metode Total Plate Count (TPC). Hasil uji TPC dari 30 sampel menunjukkan seluruh sampel terkontaminasi $E$. coli dengan koloni terbanyak adalah $2,2 \times 10^{-7} \mathrm{CFU} / \mathrm{g}$ sedangkan koloni paling sedikit adalah $5 \times 10^{-4} \mathrm{CFU} / \mathrm{g}$. Sampel yang terkontaminasi Salmonella sp terdapat 2 sampel, di pasar G dan pasar W, dengan kode D6 4,7 X 10-6 CFU/g dan kode E5 1 X $10^{-6} \mathrm{CFU} / \mathrm{g}$. Sedangkan
\end{abstract}


Staphylococcus aureus sendiri juga hanya ditemukan di pasar W dengan kode sampel E1 \& E6, masing-masing sampel memiliki koloni 2,7 X $10^{-7} \mathrm{CFU} / \mathrm{g}$ dan 2 X10-5 CFU/g.

Kata Kunci: daging ayam; Escherichia coli; Salmonella sp; Staphylococcus aureus.

\section{INTRODUCTION}

The food consumed can potentially become unsafe food and can cause a disease called foodborne disease. It is caused by consuming food contaminated by microorganisms such as bacteria, parasites, fungi, viruses, toxins, and chemicals (Sharif, Javed, and Nasir, 2018). Several pathogenic bacteria can cause foodborne diseases, such as Escherichia coli, Salmonella sp., Shigella sp., Campylobacter sp., $\quad$ Clostridium botulinum, and Clostridium pefringens (Law et al., 2014). Foodborne diseases are usually toxic or infectious, caused by disease agents that enter the body by consuming contaminated food. Sometimes this disease is called "food poisoning" (food poisoning), although this term is not correct (WHO, 2015).

To avoid contamination of food by microorganisms that cause foodborne diseases, WHO (World Health Organization) has five primary keys to keep food in a safe condition when consumed, including maintaining cleanliness, separating raw and cooked food, cooking until cooked, storing food at temperature. Safe, and use safe water and raw materials. However, most people ignore it, resulting in very sensitive food sanitation and poisoning due to microbes that cause gastrointestinal symptoms (WHO, 2014). The most common clinical symptoms of foodborne disease are gastrointestinal symptoms. However, they can also have neurological, gynecological, immunological, and other symptoms. Multiorgan failure and even cancer can occur due to contaminated foodstuffs (WHO, 2015). Food sources needed by the body contain energy, carbohydrates, protein, vitamins, and minerals. One of the food ingredients in animal protein sources is chicken (Shondelmyer et al., 2018). Until now, public demand tends to consume chicken meat compared to beef. The need for chicken meat in Indonesia is very high, especially in Surabaya, East Java Province. From 2016 to 2018, the demand for chicken meat in East Java Province, Surabaya City, increased. Data from the East Java Animal Husbandry Service shows that in 2016 the demand for chicken meat reached 13,329,671 kg, in 2017, it reached $48,391,312 \mathrm{~kg}$, and in 
2018 it reached 49,800,902 $\mathrm{kg}$ (East Java Provincial Animal Husbandry Office, 2019).

The quality of chicken meat includes physical, chemical, and biological qualities. These ingredients in food, to a certain extent, can pose a health risk. Biologically, the damage to chicken meat is mainly caused by microbes' growth originating from livestock and pollution from the environment during slaughter and marketing (Hajrawati et al., 2016). Unhygienic sales conditions, especially in traditional markets, can cause chicken meat to be contaminated by pathogenic and non-pathogenic microorganisms. Pathogenic bacteria that can contaminate chicken meat are Campylobacter sp., Salmonella $\quad s p ., \quad$ Listeria $\quad s p$. , Staphylococcus aureus, Clostridium pefringens, Escherichia coli (Rouger, Tresse, and Zagorec, 2017). Escherichia coli and Salmonella sp. are the types of bacteria in chicken meat that most often cause foodborne diseases in developing countries with diarrhea symptoms, stomach cramps, vomiting, and fever (Adeyanju and Ishola, 2014). Apart from Escherichia coli and Salmonella sp, Staphylococcus aureus bacteria can be found in raw or undercooked chicken meat samples. If consumed, it can cause infection and toxicity (Herve and Kumar, 2017). These bacteria are pathogenic for humans or animals whose habitat is in the digestive tract. Therefore, these bacteria's transmission can be through fecal-oral (contaminated food or drink) (Elliot et al., 2011). Bacterial contamination in food and beverages can cause these foods to become a medium for the disease. So that poultry and poultry products must be prevented during handling, slaughter, and processing to protect people from infection and disease (Bhaisare et al., 2014).

Ramadhani, Rukmi, and Jannah (2020) found the Escherichia coli at eight chicken meat samples in the Banyumanik traditional market in Semarang. All chicken samples contained E. coli in the range of $1.1 \times 103-2.1 \times 104 \mathrm{CFU} / \mathrm{g}$. Also, 2 out of 8 samples (25\%) of the chicken samples were contaminated with Salmonella sp. Based on the number of E. coli, all samples did not meet the SNI 3924: 2009 standard and two samples did not meet the SNI standard because they were contaminated by Salmonella $s p$. Bacteria. Jefani V, et al. (2017) also researched Staphylococcus aureus contamination in chicken meat sold in the Ulee Kareng traditional market. The results of the calculation of Staphylococcus aureus bacteria on the first 
day showed an average number of $1.5 \mathrm{X}$ 104 CFU / g (morning) and 13.9 X 104 (during the day), while on the second day showed an average level of contamination of 17, 7 x $104 \mathrm{CFU} / \mathrm{g}$ (morning) and 7.1 X 104 CFU / g (during the day). It can be concluded that the level of Staphylococcus aureus bacteria contamination in chicken meat sold in the Ulee Kareng traditional market is classified as unhygienic because it exceeds the standard value of SNI 3924: 2009. Based on previous research results, the authors will conduct further research on the prevalence of Escherichia coli, Salmonella sp, and Staphylococcus aureus found in raw chicken meat in traditional markets in Surabaya City.

\section{METHOD}

This research is a descriptive study with an observational design using the crosssectional method. The sample used in this study was 30 samples taken by random sampling. Samples in the form of chicken meat taken in 5 traditional markets, Kec. Gubeng, Surabaya City. With the following criteria: Chicken meat is purchased at several traditional markets, sellers who are willing to use the chicken meat as research samples, and the tested chicken meat is still fresh. Samples were taken on average at $08.00-09.00$ WIB.
The seller's sample is put into a sterile tube. Then the tube is put into a box for examination at the Microbiology Laboratory of the Faculty of Medicine, Airlangga University, Surabaya.

\section{Tools and Materials}

The tools used in this research were stomacher, sterile pot, test tube, blender, tube rack, tweezers, bunsen, pipette, loop needle, matches, spirit lamp, micropipette, glass object, autoclave, incubator, handscoon, mask, oil immerses, microscope, notebook, pen, petri dish, drigalski, measuring cup, label. In contrast, the materials used in this study were Chicken Meat, MacConkey Agar medium, Eosin Methylene Blue, Mannitol Salt Agar, Blood Plate Agar, Crystal Violet, Lugol, 75\% Alcohol, and Safranin, Aquades, Tissue / Filter Paper.

\section{Sample Dilution Procedure}

The sample from the sterile tube is taken aseptically. The sample does not need to be washed. The meat is taken immediately, then takes 5 grams, put in a blender sterilized, and adds $45 \mathrm{ml}$ of distilled water-homogenized until well blended. Then take a few $\mathrm{ml}$ to put it in a sterile tube. This process is to obtain a $10^{7}$ dilution solution. Then $0.5 \mathrm{ml}$ of the $10^{\urcorner}$ dilutions was taken and put into a test tube containing $4.5 \mathrm{ml}$ of distilled water to 
obtain a $10^{-}$dilution. Transfer $0.5 \mathrm{ml}$ of the sample from $10^{2}$ into a test tube containing $4.5 \mathrm{ml}$ of distilled water to obtain $10^{3}$. Do this with the same procedure until getting a 10-5 dilution.

\section{Identification of Escherichia coli and Salmonella sp}

For the examination of Escherichia coli and Salmonella sp. Colonies taken for testing were obtained from Mac Conkey Agar medium. For each dilution, take as much as $0.5 \mathrm{ml}$ using a micropipette from the test tube. Drop it into a MacConkey Agar petri dish which is already solid, then flattened using drigalski; beforehand, the drigalski must be passed over the fire bunsen to make it sterile. Samples were incubated at $37^{\circ} \mathrm{C}$ for 24 hours. Colony growth of each Escherichia coli and Salmonella sp on MacConkey Agar was calculated using Colony counter. Escherichia coli and Salmonella sp. are Gram-negative bacteria to be grown on MacConkey Agar media. Escherichia coli colonies in this medium were characterized by colonies that were pink/pink in color (lactose fermenter) while colonies of Salmonella sp. Were pale/colored almost the same as the medium (non-lactose fermenter). Next, count the colonies using a colony counter. To confirm Escherichia coli bacteria, take eight colonies that are pink/pink and then plant them on Eosin Methylene Blue (EMB) media. In this medium, Escherichia coli has a characteristic appearance with the appearance of green metallic sheen. After obtaining the description, a biochemical test is performed. The non-lactose fermenter colonies that were suspected of being Salmonella sp. Then performed microscopic examination with the Gram stain of the bacteria and Gram-negative rods. Moreover, it continued with biochemical tests.

S. aureus is a Gram-positive cocci bacteria, so identifying the planting was carried out in Mannitol Salt Agar. Each dilution takes $0.5 \mathrm{ml}$ using a micropipette from a test tube and drops it into a Mannitol Salt Agar dish in this medium S. colony. Aureus is a colony surrounded by a yellow zone. Next, implant it on a Blood Plate Agar medium to see the beta hemolysis zone's image. S. aureus in the catalase test showed air bubbles, and in the coagulase test, it could form clots or jelly, and when the tube was tilted, the jelly remained at the bottom of the tube. Data on the examination results were reported in the form of a percentage of the samples contaminated with Escherichia coli, Salmonella sp, and Staphylococcus aureus. 
U.D. Karisma, N. Wiqoyah, S. Pusarawati, Prevalence of Escherichia Coli, 198 Salmonella Sp, Staphylococcus Aureus Bacteria in Chicken Meat of Traditional Market Surabaya City

Descriptive analysis by counting the number of these bacteria in the sample and the number of samples that meet the maximum limit requirements for the number of Escherichia coli, Salmonella sp, and Staphylococcus aureus in the sample based on the Maximum Limit of Microbial Contamination of SNI 3924-2009. This study was accompanied by a review letter from the Health Research Ethics Committee of the Faculty of Medicine, Airlangga University No. 319 / EC / KEPK / FKUA / 2019.

\section{RESULTS AND DISCUSSION}

Based on the test results from 30 samples of chicken meat obtained from 5 traditional markets in Surabaya, it was found that the contamination of Escherichia coli, Salmonella sp, and Staphylococcus aureus bacteria were found. The level of contamination each has a different number of colonies can be seen in table

\section{Calculation of Bacterial Colonies :}

Number of colonies $=$ number of colonies on a plate $\mathrm{x} 1 /$ dilution factor 
Table 1. The number of bacterial colonies of Escherichia coli, Salmonella sp, Staphylococcus aureus found in raw chicken meat sold in traditional markets in Surabaya City.

\begin{tabular}{|c|c|c|c|}
\hline Sample Code & $\begin{array}{l}\text { E. coli } \\
\text { CFU/g }\end{array}$ & $\begin{array}{c}\text { Salmonella sp } \\
\text { CFU/g }\end{array}$ & $\begin{array}{c}\text { S.aureus } \\
\text { CFU/g }\end{array}$ \\
\hline $\mathrm{A} 1$ & $7,6 \times 10^{-5}$ & - & - \\
\hline $\mathrm{A} 2$ & $2 \times 10^{-5}$ & - & - \\
\hline $\mathrm{A} 3$ & $6 \times 10^{-5}$ & - & - \\
\hline A4 & $6,4 \times 10^{-4}$ & - & - \\
\hline A5 & $5 \times 10^{-4}$ & - & - \\
\hline A6 & $1,8 \times 10^{-5}$ & - & - \\
\hline B1 & $>300 \times 10^{-5}$ & - & - \\
\hline $\mathrm{B} 2$ & $5 \times 10^{-5}$ & - & - \\
\hline B3 & $30 \times 10^{-5}$ & - & - \\
\hline B4 & $1,05 \times 10^{-7}$ & - & - \\
\hline B5 & $1 \times 10^{-7}$ & - & - \\
\hline B6 & $1,74 \times 10^{-7}$ & - & - \\
\hline $\mathrm{C} 1$ & $2 \times 10^{-5}$ & - & - \\
\hline $\mathrm{C} 2$ & $>300 \times 10^{-5}$ & - & - \\
\hline $\mathrm{C} 3$ & $2,3 \times 10^{-6}$ & - & - \\
\hline $\mathrm{C} 4$ & $49 \times 10^{-5}$ & - & - \\
\hline $\mathrm{C} 5$ & $1,85 \times 10^{-5}$ & - & - \\
\hline C6 & $>300 \times 10^{-5}$ & - & - \\
\hline D1 & $4 \times 10^{-5}$ & - & - \\
\hline D2 & $5,3 \times 10^{-6}$ & - & - \\
\hline D3 & $4 \times 10^{-5}$ & - & - \\
\hline D4 & $3,8 \times 10^{-6}$ & - & - \\
\hline D5 & $9 \times 10^{-5}$ & - & - \\
\hline D6 & $2,9 \times 10^{-6}$ & $4,7 \times 10^{-6}$ & - \\
\hline $\mathrm{E} 1$ & $1,6 \times 10^{-6}$ & - & $2,7 \times 10^{-6}$ \\
\hline E2 & $9 \times 10^{-5}$ & - & - \\
\hline E3 & $1 \times 10^{-7}$ & - & - \\
\hline E4 & $1,7 \times 10^{-6}$ & - & - \\
\hline E5 & $2,2 \times 10^{-7}$ & $1 \times 10^{-6}$ & - \\
\hline E6 & $4 \times 10^{-6}$ & - & $2 \times 10^{-5}$ \\
\hline SNI Standard & $1 \times 10^{-1}$ & Negatif/25 g & $1 \times 10^{-1}$ \\
\hline
\end{tabular}


The test results of Escherichia coli, Salmonella sp, and Staphylococcus aureus bacteria were conducted at the Microbiology Laboratory of the Faculty of Medicine, Airlangga University. It was found that all samples were contaminated with Escherichia coli bacteria that exceeded the maximum limit requirements for microbial contamination, namely $1 \mathrm{X}$ 10-1 colony / g. For Salmonella sp and Staphylococcus aureus bacteria, not all samples can be found. It is probably due to contamination during the cutting process to the distribution process and about cleanliness in the marketing process until it reaches consumers.

The part of chicken meat used as the sample was taken randomly. Sampling in traditional markets because the total microbes of chicken meat sold in traditional markets are more than in modern markets/supermarkets. Following the opinion of Kurniati, N. \& Shufiyani (2015), which states that among the four samples tested, there was contamination in 1 sample of chicken meat from traditional markets. The chicken meat sample taken from the supermarket was not contaminated with $E$. coli bacteria, and the Chicken meat sample in supermarkets fulfills the SNI requirements. In contrast, for chicken meat samples from traditional markets, one does not meet the SNI requirements. The number of microbes is influenced by market sanitation. The modern market selling chicken meat has good sanitation and has hygienic packaging and is stored at low temperatures to reduce pathogenic bacterial contamination (Sartika, Susilawati, and Arfani, 2016).

This study's traditional markets are GM Market, PA Market, TR Market, G Market, and W Market. These markets were chosen in this study because there are $\geq$ six chicken meat sellers. When viewed from the perspective of sampling locations taken at traditional markets in Surabaya, almost all of the places where the sales are clean are not maintained. Because the places selling chicken meat in GM Market, PA Market, GB Market, and W Market are still placed on wooden tables with plinths. Inadequate and in these markets, the chicken meat seller mixes up to allow for a high total bacterial count. Based on the observations' results, the market has inadequate clean water facilities and a minimum supply of trash cans. At TR Market, a place to sell, a permanent table has been provided with a ceramic floor. A place for selling chicken meat has been 
provided so that it does not mix with other foodstuff sellers, and a running water facility has been provided in several places. The high total of microbes contained in the chicken meat sample was caused by less hygienic handling. The chicken meat condition in the open air could condition the growth of microbes in chicken meat, both pathogenic and nonpathogenic microbes, and the condition of the chicken meat that was only placed. The absence of a cooling or freezing process can promote bacterial growth. It is the opinion according to Soeparno (2009), which states that refrigeration can inhibit bacterial growth. If the refrigerant does not continue well, the growth of microorganisms will increase, which can cause changes in meat quality.

Table 2. Percentage of chicken meat contaminated by E. coli, Salmonella sp, and S. aureus bacteria

\begin{tabular}{ccc}
\hline Name of Bacteria & Number of Samples & Percentage (\%) \\
\hline Escherichia coli & 30 & $100 \%$ \\
Salmonella sp & 2 & $6,67 \%$ \\
Staphylococcus aureus & 2 & $6,67 \%$ \\
\hline
\end{tabular}

In table 2 it can be concluded that from 30 samples of chicken meat, it was found that all samples $(100 \%)$ were contaminated with Escherichia coli, two samples $(6.67 \%)$ were contaminated with Salmonella sp, and two samples were also (6.67\%) contaminated with Staphylococcus aureus. From these results, it is known that there are samples contaminated with more than 1 type of bacteria, namely samples D6, E1, E5, E6. So if it is viewed from the table above, the bacteria that most contaminates chicken meat in the traditional market is Escherichia coli, whose colony numbers do not meet SNI standards. It follows the research results conducted by Rafika, Irmawaty, and Khaerani (2018) from 24 samples of chicken meat obtained from Makassar traditional markets where $100 \%$ of the chicken meat samples were contaminated Escherichia coli, and all of them exceeded the threshold set by SNI.

In this study, comparing the TR market with other markets is quite different. The difference is that the TR market has been renovated so that there is a special place for selling meat. However, the least amount of Escherichia coli bacteria was taken in A5 samples on the GM market. When viewed from the point of view of 
where the A5 seller is not much different from other sellers, other factors influence it, such as the slaughtering process or during the distribution process. Alternatively, possibly influenced by the time factor, the GM market is one of the closest markets to the Lab when viewed from the location. FK Unair Microbiology. So that, according to researchers, a special place for selling meat does not rule out the possibility of the meat being protected from bacteria. The most important thing to minimize bacterial growth is to frequently clean the place used for buying and selling or cleaning the surrounding environment. For chicken meat sellers in traditional markets, it is advisable to provide a water tub/sink at the place of sale to avoid crosscontamination. This cross-contamination comes from the hands of buyers who come into direct contact with chicken meat. According to Rafika, Irmawaty, and Khaerani (2018), dirty equipment can become a growth medium for microorganisms so that crosscontamination can occur from carcass to carcass.

The more microorganisms that contaminate chicken meat, if consumed without proper processing, will cause health problems. Food processors play a crucial role in food hygiene efforts because they can transmit diseases that can be transmitted through food or drink. Therefore, personal hygiene is essential for food processors. Based on this research process, there are several limitations experienced by researchers, among others: 1.) this study only took 30 samples, 2.) there was a limited research time because this study also adjusted the existing schedule on campus, 3.) some sellers who refused to take their chicken meat as research samples, 4.) honesty when answering questions about the time of slaughter, so it is possible to get inaccurate data because it is only based on estimated time.

\section{CONCLUSION}

Based on the requirements for the microbiological quality of chicken meat according to SNI 3924: 2009, the level of contamination of $\mathrm{E}$. coli bacteria in chicken meat samples from traditional markets is $100 \%$ does not meet SNI standards. In contrast, the level of contamination of Salmonella $\mathrm{sp}$ and Staphylococcus aureus bacteria is only six, respectively (7\%), which do not meet SNI standards. The source of this contamination may come from the 
equipment used, the cleanliness of the surrounding environment, and the chicken meat seller's hygiene.

\section{ACKNOWLEDGEMENT}

In completing this research, the author can resolve many obstacles and can be resolved thanks to the guidance, assistance, and support of various parties, which, in the end, this writing can be completed as it is. The author would like to thank all those who have helped in the research process until it was completed.

\section{REFERENCES}

Adeyanju, G. T. and Ishola, O. (2014). Salmonella and escherichia coli contamination of poultry meat from a processing plant and retail markets in Ibadan, Oyo state, Nigeria. SpringerPlus, 3(1), 1-9. DOI: 10.1186/2193-1801-3-139.

Bhaisare, D. B. et al. (2014). Bacterial Pathogens in Chicken Meat: Review. International Journal of Life Sciences Research, 2(3), 2348313.

Hajrawati, H. et al. (2016). Kualitas Fisik, Mikrobiologis, dan Organoleptik Daging Ayam Broiler pada Pasar Tradisional di Bogor. Jurnal Ilmu Produksi dan Teknologi Hasil Peternakan, 4(3), 386-389. DOI: 10.29244/jipthp.4.3.386-389.

Herve, D. T., and Kumar, G. (2017). Prevalence of Staphylococcus aureus in retail chicken meat samples in Jalandhar, Punjab. Research Journal of Pharmacy and
Technology, 10(1), 281-285. DOI: 10.5958/0974-360X.2017.00058.0.

Kurniati, N. \& Shufiyani. (2015). Identifikasi Cemaran Escherichia Coli Pada Daging Ayam Dari Pasar Tradisional Dan Supermarket. Jurnal medikes. 3(2).

Law, J. W. F. et al. (2014). Rapid methods for the detection of foodborne bacterial pathogens: Principles, applications, advantages and limitations. Frontiers in Microbiology, 5(DEC), 1-19. DOI: 10.3389/fmicb.2014.00770.

Rafika, N., Irmawaty and Khaerani, K. (2018). Tingkat Cemaran Bakteri Escherischia coli Pada Daging Ayam Yang Dijual Di Pasar Tradisional Makassar. Prosiding Seminar Nasional Megabiodiversitas Indonesia Universitas Alauddin Makasar, (April), 42-50.

Ramadhani, W. M., Rukmi, I. and Jannah, S. N. (2020). Kualitas mikrobiologi daging ayam broiler di pasar tradisional Banyumanik Semarang. Jurnal Biologi Tropika, 3(1), 8-16.

Rouger, A., Tresse, O. and Zagorec, M. (2017). Bacterial Contaminants of Poultry Meat: Sources, Species, and Dynamics. Microorganisms, 5(3), 50 .

DOI: 10.3390/microorganisms5030050.

Sartika, D., Susilawati and Arfani, G. (2016). Identifikasi Salmonela $\mathrm{sp}$ pada ayam potong. Teknologi Industri dan Hasil Pertanian, 21(2), 89-96.

Sharif, M. K., Javed, K. and Nasir, A. (2018). Foodborne Illness: Threats and Control, Foodborne Diseases. Elsevier Inc. doi: 10.1016/B978-0- 
U.D. Karisma, N. Wiqoyah, S. Pusarawati, Prevalence of Escherichia Coli, 204 Salmonella Sp, Staphylococcus Aureus Bacteria in Chicken Meat of Traditional Market Surabaya City

$12-811444-5.00015-4$

Shondelmyer, K. et al. (2018). Focus: Nutrition and Food Science: Ancient Thali Diet: Gut Microbiota, Immunity, and Health. The Yale Journal of Biology and Medicine, 91(2), 177.

Soeparno. (2009). Ilmu dan Teknologi Daging. Yogyakarta: Gadjah Mada University Press.
WHO. (2014). Nutrition and food security. [Online] Available From : https://www.who.int/foodsafety/area s_work/nutrition/en/ [Accessed 25 Mei 2019]

WHO. (2015). Foodborne Disease. [Online] Available From : https://www.who.int/topics/foodbor ne_diseases/en/ [Accessed 4 Mei 2019] 